\title{
THE BUSINESS CORPORATIONS ACT - THE DISTINCTION BETWEEN BYLAWS AND ARTICLES OF ASSOCIATION
}

\author{
R.W. EWASIUK*
}

Since the proclamation of the Business Corporations Act ${ }^{1}$, a rather unfortunate practice has grown up among many of Alberta's practitioners concerning the treatment and content of a corporation's Bylaws. On continuation of client corporations, many practitioners have merely reinstated slightly modified versions of the existing Articles of Association and have termed them "the Bylaws". Similarly, with respect to new incorporations, many practitioners have simply enacted modified versions of their old Articles of Association precedents. Other practitioners, while recognizing the necessity for major modifications to the Articles of Association on continuation have, nonetheless, deemed it advisable to preserve certain provisions of the Articles of Association in the Bylaws on the theory that it is most of ten desirable to preserve the status quo. The rationale for placing such provisions in the Bylaws is that subsequent alterations would not require the unanimous consent needed if the provisions were placed in a Unanimous Shareholder Agreement, ${ }^{2}$ or the 2/3 majority ${ }^{3}$ required (and would avoid the risk of a possible triggering of dissenting shareholders' rights ${ }^{4}$ ) if the provisions were placed in the Articles of Continuation (or Articles of Incorporation, as the case may be).

The purpose of this note is to briefly illustrate the fundamental differences between the Bylaws, as contemplated by the Business Corporations Act, and the Articles of Association as contemplated by the Alberta Companies Act. ${ }^{5}$ Specific examples will be used to point out the risks of incorporating into the Bylaws of a corporation continued or incorporated under the Business Corporations Act any provision not specifically authorized by the Act to be in the form of a Bylaw.

The Business Corporations Act does not contain any provisions which attempt to define exactly what the "Bylaws" of a corporation are. Similarly, no attempt has been made in the Act to outline what effect the Bylaws have upon the shareholders, the corporation, or the directors. Rather, the Act, in any given instance, makes mention of the Bylaws in one of two ways. In some cases it may be stated expressly that the Bylaws "may" provide for some matter or, alternatively, that some thing will be or that some result will follow "unless the Bylaws otherwise provide". In other cases there is only the implication that the Bylaws can provide for some matter by wording to the effect that "subject to the Bylaws" some thing will be or some result will follow. Aside from those references, however, nothing more is said.

It is suggested that the result of such wording (or lack of wording) is that a provision placed in the Bylaws of a corporation that is not specifically

* With the firm of Reynolds, Mirth and Cote in Edmonton.

1. S.A. 1981 , c. B-15.

2. Section $140(8)$. Note that by s. $140(9)$ it cannot be provided in a Unanimous Shareholder Agreement that the agreement may be amended by less than unanimous consent.

3. See ss. 1(y) and 167.

4. See s. 184 .

5. Now R.S.A. 1980 , c. C-20. 
authorized by the Act is not enforceable either as against the corporation or the shareholders ${ }^{6}$. After all, in the absence of a contract or of a statutory provision imposing the enforceability of such a provision, it is difficult to imagine any principle of law which would make such provisions binding in all cases.

On first reflection, that same argument may seem equally applicable to the Articles of Association, yet no one (at least recently) has seriously disputed the enforceability of provisions in the Articles of Association not specifically authorized by the Companies Act or its predecessors. However, the differences between the Bylaws contemplated by the Business Corporations Act and the Articles of Association contemplated by the Companies Act are fundamental:

(a) Public Record: Unlike the Articles of Association, the Bylaws are not an incorporating document. Indeed, there is no requirement under the Business Corporations Act that there be any Bylaws at all. This has the consequence that the Bylaws are not filed with the Registrar and hence are not available for inspection by the public. Furthermore, the Business Corporations Act ${ }^{7}$ specifically excludes the application of the old constructive notice doctrine. It follows that a person purchasing shares in a corporation will not be artifically deemed to have knowledge of the contents of the Bylaws even if they were, for some reason, filed with the Registrar. Under the Companies Act, on the other hand, everyone, including a creditor or prospective share purchaser, is deemed to be fully appraised of the Company's Articles of Association and no one can successfully contend that he entered into a transaction in ignorance of their content. ${ }^{8}$

(b) Execution: Under the Companies Act, the Articles of Association have to be signed by all of the incorporating shareholders and their signatures witnessed. ${ }^{9}$ Hence, the Articles of Association constitute an initial unanimous agreement between the existing shareholders of the company. Under the Business Corporations Act, the Bylaws need never be signed by anyone and a unanimous agreement is not required at any time whatsoever.

(c) Enactment and Amendment: Although unanimous consent is required to enact a company's first set of Articles of Association, the Companies Act statutorily provides ${ }^{10}$ that amendments can be made by a special shareholders' resolution, which, under that Act, requires a 75 per cent majority ${ }^{11}$. Under the Business Corporations Act, however, the Bylaws can be enacted or amended by ordinary resolution of the Directors ${ }^{12}$. The Bylaws thus enacted or amended are fully operative and binding until the next shareholders' meeting at which time they may be confirmed or rejected by the shareholders, by mere ordinary resolution.

6. Obviously, in any given situation, there may be some sort of estoppel or contract argument for enforcing a particular provision based upon reliance, etc.. This is hardly the sort of argument one would want to be left with in litigation.

7. Section 17.

8. Ernest v. Nicholls (1857) 10 E.R. 1351; Peel's Case (1867) 2 Ch. App. 674; Mahoney v. East Holyford Mining Co. (1875) L.R.H.L. 869.

9. Section 24 .

10. Section 55 .

11. Section 1(y).

12. Section 98 . 
(d) The Articles as a Contract: Section 29(1) of the Companies Act provides as follows:

29(1) The memorandum and articles, when registered, bind the company and the members there of to the same extent as if they respectively had been signed and sealed by each member, and contained covenants on the part of each member, his heirs, executors, and administrators, and in the case of a corporation, its successors, to observe all the provisions of the Memorandum and of the Articles, subject to the provisions of this Act.

This section is subject to varied interpretations, but it and its predecessors, viewed together with the points raised above, have given rise to the now well-established principle ${ }^{13}$ that the Articles of Association are a contract between the corporation and the shareholders, and between the shareholders inter se. The Business Corporations Act has no section comparable to section 29(1) of the Companies Act. In the absence of such a section, and given the points raised above, it is difficult to imply a similar contract in respect of the provisions of the Bylaws.

(e) Table A: Aside from section 29(1), the Companies Act, like the Business Corporations Act with respect to its Bylaws, does not attempt to define what the Articles of Association are. However, Table " $A$ ", by implication, provides examples of what sorts of provisions (for example, "the casting vote provision") are permissible. Once again, however, there is no provision or schedule in the Business Corporations Act comparable to Table "A".

It is in the nature of corporate law that the corporate constitution, particularly in the case of private companies, is seldom relied upon or enforced (or even looked at) unless there is a dispute between the shareholders. Hence it is really only in litigation or in contemplation of litigation that the Bylaws will be looked at in detail and, obviously, at that time there will be at least one party that will be seeking to find some grounds for attacking a Bylaw's enforceability. Many of the provisions now being placed in the Bylaws of corporations would be of fundamental importance in just such an event. Some examples of such provisions are the following:

(a) Pre-emptive Rights: Under the Companies Act, a provision in the Articles of Association that shares of the corporation cannot be issued to a non-shareholder without first offering those shares to the existing shareholders is not uncommon. Section 25(1) of the Business Corporations Act reads as follows:

25(1) Subject to the Articles, the Bylaws and any Unanimous Shareholder Agreement, and to Section 28, shares may be issued at the times and to the persons and for the consideration that the directors determine.

At first glance, the wording in section 25(1) seems to imply that the Bylaws could contain a restriction on issuance in the nature of a preemptive right. However, section 28(1) provides as follows:

28(1) If the Articles or a Unanimous Shareholder Agreement so provide, no shares of a class shall be issued unless the shares have first been offered to the shareholders holding shares of that class, and those shareholders have a pre-emptive right to acquire the offered shares in proportion to their holdings of the shares of that class, at the same price and on the same terms as those shares are to be offered to others.

It appears, therefore, that pre-emptive rights, while permissible in the Articles or in a Unanimous Shareholder Agreement, are not to be pro-

13. The locus classicus is Hickman v. Kent or Romney Marsh Sheep Breeders' Association [1915] 1 Ch. 881. 
vided for in the Bylaws. On comparison with section 28(1), the wording in section 25(1) appears to be more permissive in nature, in that it provides for what the directors can do, as opposed to what restrictions can be placed in the Bylaws. In other words, the proper interpretation of section 25(1) is probably that the directors have the power to issue shares provided such issuance is not contrary to valid provisions of the Bylaws, whatever they may be. It is merely an exception and does not of itself imply what provisions are valid.

(b) Rights of First Refusal: As in the case of the pre-emptive right, a provision in the Articles of Association that a share of the corporation cannot be transferred to a non-shareholder without first offering that share to the existing shareholders, is not uncommon. In this case, however, there are no provisions in the Business Corporations Act comparable to section 25(1) to even imply that such a provision is permissible in the Bylaws. Furthermore, section 6(1)(c) provides as follows:

6(1) The Articles of Incorporation shall be in the prescribed form and shall set out, in respect of the proposed corporation...

(c) if the right to transfer shares of the corporation is to be restricted, a statement that the right to transfer shares is restricted and either

(i) a statement of the nature of the restrictions, or

(ii) a statement that the nature of the restrictions appears in an Unanimous Shareholder Agreement.

Once again it seems clear that a restriction on transfer, while permissible in the Articles of Incorporation or in a Unanimous Shareholder Agreement, ought not to be placed in the Bylaws. This, after all, only makes sense. It would be an absurd situation if the directors of a corporation were allowed to fundamentally affect the ability of the shareholders, even temporarily, to deal with their shares.

(c) Casting Vote: Once again, it is not uncommon under the Companies Act to provide in the Articles of Association that the Chairman of a Shareholders' or Directors' meeting has an additional vote in the event of a tie. Needless to say, the casting vote provision is an extremely important one and may ultimately determine control of the corporation. However, the Business Corporations Act is completely silent about casting votes. It may be permissible to deal with casting votes by a Unanimous Shareholder Agreement on the argument that such a provision, in respect of shareholders' meetings, is a regulation of the rights and liabilities of the shareholders as between themselves, as contemplated by section 140(1)(a). With respect to Directors' meetings, it could be argued that such a provision is for the management of the business and affairs of the corporation, as contemplated by section 140(1)(c). It is also possible that by implication of section 134(1), the provision can be placed in the Articles of Incorporation. However, it seems quite clear that such a provision cannot be placed in the Bylaws.

(d) Limitation on Numbers: Under the Business Corporations Act, the distinction between "private" and "public" companies has been abolished in favour of a distinction based upon what has actually taken place in the distribution of a corporation's shares. The Business Corporations Act now distinguishes between corporations having 15 or fewer shareholders, corporations having more than 15 shareholders and whose issued shares were a part of a distribution to the public (known as "distributing corpora- 
tions"), and corporations having more than 15 shareholders which are not distributing corporations. Hence there is no longer a requirement under the Business Corporations Act that the number of shareholders be limited to less than 50 or, it is suggested, even that there be anything in the corporate constitution which purports to prevent the corporation from distributing its securities to the public ${ }^{14}$.

However, as of this writing, the Securities Act ${ }^{15}$ has not yet been amended to reflect this new distinction. The Securities Act, while providing a general exemption in respect of both trades ${ }^{16}$ and take-over bids ${ }^{17}$ of the shares of a "private company" has failed to provide the same exemption for the shares of non-distributing corporations. Hence, a number of practitioners have been preserving the old private company restrictions in order to retain this exemption for both continued and newly incorporated companies. Many have been doing this by placing the restrictions in the Articles of Incorporation. While this method is not entirely without difficulty,$^{18}$ it is certainly preferable to placing these restrictions in the Bylaws. Such a restriction constitutes both a restriction on issuance and on transfer, and as stated above, there is nothing in the Business Corporations Act, outside of section 25(1), which can be taken as authorizing such a placement. In any event, the Securities Act ${ }^{19}$ makes it clear that for the exemption to apply such a restriction must be placed in the corporation's "instrument of incorporation". The Bylaws clearly are not an instrument of incorporation.

The above are, of course, only examples, and there are other provisions commonly contained in the Articles of Association that ought not to be carried forward into the Bylaws. Such provisions may not be of such major impact as the examples given above, but they may, in any given situation, be clauses that must be relied upon by a shareholder or by the corporation. With respect, it must be recognized that at the very least, there are considerable risks in placing these provisions in the Bylaws. Such risks far outweigh any advantage to be gained by placing them in the Bylaws for the sake of easy amendment.

14. See the definition of "distributing corporations" in s. 1(i). The test is one to be applied in hindsight. Either the corporation has distributed to the public or it has not. Whether its constitution states that it can or cannot do so is irrelevant.

15. S.A., 1981, c. S.6.1.

16. Section $66(j)$.

17. Section 132(1)(b).

18. Section 6(1)(c) deals only with the transfer of shares. Quaere, whether s. 25 of the Business Corporations Act is worded broadly enough to allow the Articles of Incorporation to contain a restriction on issuance.

19. See s. 1(p.1). 